\title{
Operational satellite-based temporal modelling of Aedes population in Argentina
}

\author{
Manuel Espinosa, ${ }^{1}$ Eliana Marina Alvarez Di Fino, ${ }^{1,3}$ Marcelo Abril, ${ }^{1}$ Mario Lanfri, ${ }^{2}$ \\ Maria Victoria Periago, ${ }^{1}$ Carlos Marcelo Scavuzzo ${ }^{2}$ \\ ${ }^{1}$ Mundo Sano Foundation, Buenos Aires; ${ }^{2}$ Mario Gulich Institute for Higher Space Studies, Teófilo \\ Tabanera Space Center, Córdoba; ${ }^{3}$ School of Nutrition, Faculty of Medical Sciences, \\ National University of Córdoba, Argentina
}

\begin{abstract}
Aedes aegypti is a vector for Chikungunya, Dengue and Zika viruses in Latin America and is therefore a large public health problem for the region. For this reason, several inter-institutional and multidisciplinary efforts have been made to support vector control actions through the use of geospatial technologies. This study presents the development of an operational system for the application of free access to remotely sensed products capable of assessing the oviposition activity of Ae. aegypti in all of Argentina's northern region with the specific aim to improve the current Argentine National Dengue risk system. Temporal modelling implemented includes remotely sensed variables like the normalized difference vegetation index, the normalized difference water index, day and night land surface temperature and precipitation data available from NASA's tropical rainfall measuring mis-
\end{abstract}

Correspondence: Manuel Espinosa, Mundo Sano Foundation, Paraguay
1535, C1061ABC, Buenos Aires, Argentina.
Tel.: 54.11.48721333 - Fax: 54.11.48721334.
E-mail: mespinosa@mundosano.org

Key words: Aedes aegypti; Dengue; Modelling; Remote sensing; Argentina.

Contributions: ME, data collection, writing and review of the manuscript; EMADF, data analysis and writing of the manuscript; MA study conception and review of the manuscript; MVP, editing and translation of the manuscript; ML and CMS, study conception, verification of analysis and review of the manuscript.

Conflict of interest: the authors declare no potential conflict of interest.

Funding: Fundación Mundo Sano.

Received for publication: 28 August 2018.

Accepted for publication: 4 September 2018.

CCopyright M. Espinosa et al., 2018

Licensee PAGEPress, Italy

Geospatial Health 2018; 13:734

doi:10.4081/gh.2018.734

This article is distributed under the terms of the Creative Commons Attribution Noncommercial License (CC BY-NC 4.0) which permits any noncommercial use, distribution, and reproduction in any medium, provided the original author(s) and source are credited. sion and global precipitation measurement. As a training data set, four years of weekly mosquito oviposition data from four different cities in Argentina were used. A series of satellite-generated variables was built, downloading and resampling the these products both spatially and temporally. From an initial set of 41 variables chosen based on the correlation between these products and the oviposition series, a subset of 11 variables were preserved to develop temporal forecasting models of oviposition using a lineal multivariate method in the four cities. Subsequently, a general model was generated using data from the cities. Finally, in order to obtain a model that could be broadly used, an extrapolation method using the concept of environmental distance was developed. Although the system was oriented towards the surveillance of dengue fever, the methodology could also be applied to other relevant vector-borne diseases as well as other geographical regions in Latin America.

\section{Introduction}

Mosquitoes are the most important vectors of human infectious diseases in the world, Aedes aegypti in particular. It is the main vector of dengue, chikungunya, zika and urban yellow fever (Liang et al., 2015). Due to the absence of vaccines for most of these viruses, and the possibility of introduction of other viruses and/or emergence of new diseases (Vasconcelos and Calisher, 2016), vector control is the main tool to control their spread. Transmission is influenced by factors including vector density, virus circulating and human susceptibility (Christophers, 1960). Moreover, the association between the first two factors and climatic variables has been proven, especially with respect to the average daily temperature (Lambrechts et al., 2011; Eisen et al., 2014; Estallo et al., 2015; Mordecai et al., 2017). In Argentina, Ae. aegypti is the most relevant mosquito an the epidemiologic point of view. This vector is characterized by its presence in urban environments, its preference for breeding in artificial containers (Rueda et al., 1990), its egg resistance to desiccation and the feeding behaviour of the female, which bites in multiple occasions during each gonadotrophic cycle (Focks et al., 1993a, 1993b). Ovitraps provide useful information on spatial and temporal distributions of Ae. aegypti, allowing monitoring of vector activity (Ritchie, 1984) to determine, for example, when and where the most effective vector control activities should take place (Wong et al., 2011; WHO, 2016). Important progress has been made on the epidemiology of dengue and other vector-borne and zoonotic diseases, such as Chagas, malaria, leishmaniasis and hantavirus based on the interdisciplinary concept of landscape epidemiology, 
which is focused on producing spatial and temporal predictive risk maps based on environmental landscape features together with field data (Porcasi et al., 2005, 2006; Salomón et al., 2006; Arboleda et al., 2009; Estallo et al., 2011, 2012; Polop et al., 2008; Sarfraz et al., 2014; Rocchini et al., 2015; Espinosa et al., 2016a, 2016b; Rotela et al., 2017). These Latin American studies, based on the use of space technology to solve epidemiological problems, take their cue from pioneer studies carried out in United States and Europe (Beck et al., 2000; Hay 2000; Tran et al., 2004; Ostfeld et al., 2005). In 2011, Argentina started to develop an operational dengue project called health early warning system aimed at health authorities and researchers. This tool is basically a dynamic risk map covering all cities in the country (where each city is represented as a point with a determined risk for each year), based on geospatial technology in an inter-disciplinary and inter-institutional context (Porcasi et al., 2012). This platform, developed using Open Source Software in order to generate a free service, is based on four components: entomological, viral, control and environmental. The first three consist of inputs from health agents working in each city and the fourth uses satellite-generated data. This environmental component, in the initial version of the system, had a constant probability of vector presence and a variable module related to the number of viral cycles as a function of the temperature. This fixed probability map (species presence probability map - niche model) is clearly a strong simplification and could be improved. Variables like precipitation and temperature, with local variability, have proven to influence mosquito development, survival, oviposition and vector abundance, therefore disease outbreaks could be better estimated using these variables as a base (Hopp and Foley, 2001; Morin et al., 2013; Estallo et al., 2012, 2016; Waide et al., 2013; Ostfeld et al., 2005, Morin et al., 2015). The sensor moderate resolution imaging spectroradiometer (MODIS) onboard the Earth-observational satellites Terra and Aqua is one of the most suitable for this particular application, due to its temporal, spectral and spatial resolutions provided in sets of preprocessed, freely available products (Tatem et al., 2004) related to vegetation, surface radiation, and land cover (Justice et al., 2002). Specifically, the normalized difference vegetation index (NDVI) and the land surface temperature (LST) products are examples of remotely sensed variables often used in epidemiological applications (Butt et al., 2011; Porcasi et al., 2012). The normalized difference water index (NDWI) is another useful environmental variable obtained from satellites which can monitor changes in the water content of leaves, while the Tropical Rainfall Measuring Mission (TRMM) and the Global Precipitation Measurement (GPM) provide precipitation datasets that are of value (Gu et al., 2007). All these environmental data are highly important in the study of mosquito behaviour.

In this framework, the overall objective of this study was to improve the operative application presented by Porcasi et al. (2012) (at the national scale) by incorporating a dynamic forecast for vector population modelling. The work continued using freeaccess remotely sensed products to assess Ae. aegypti oviposition activity estimations extending the reach to all of the North Argentinean region, a high-risk area for dengue, chikungunya and zika transmission. In addition, a strategy to extrapolate the models based on the concept environmental distance was incorporated.

\section{Materials and Methods}

The methodology is based on a series of previous studies (Estallo et al., 2012, 2015, 2016; German et al., 2018) but oriented towards an operational application. In particular, we included the modelling of four different cities based on a four-year field data time series and with the following environmental remotely sensed variables as predictors: NDVI, NDWI, $\mathrm{LST}_{\text {day }}$ and $\mathrm{LST}_{\text {night }}$ and precipitation (TRMM and GPM) as well as two integral LST variables from the previous year expressing temperatures with a threshold of $10^{\circ} \mathrm{C}$ (see below). Additionally, we incorporated a strategy to extrapolate the models developed in the towns, from which we have field data, to all other towns based on an environmental distance concept: that is, we engaged in building predictive models of Ae. aegypti oviposition activity based on the similarity (from an environmental point of view) between North Argentina and these cities.

\section{Study area}

The four cities used to build the models are presented in Figure 1: i) Tartagal $(80,000$ inhabitants) is located on the Argentinean north-west $\left(22^{\circ} 32^{\prime} \mathrm{S}, 63^{\circ} 49^{\prime} \mathrm{W}\right)$ and has an altitude of $450 \mathrm{~m}$. The city has a subtropical native forest environment in addition to crops. Its climate is subtropical with an average annual temperature about $23^{\circ} \mathrm{C}$ (summer average maximum of $39^{\circ} \mathrm{C}$ and winter average minimum of $9^{\circ} \mathrm{C}$ ). It has an annual precipitation of 1,100 $\mathrm{mm}$, with a dry season from June to October. ii) Clorinda $(60,000$ inhabitants) is located on the Argentinean north $\left(25^{\circ} 17^{\prime} \mathrm{S}\right.$, $\left.57^{\circ} 43^{\prime} \mathrm{W}\right), 4 \mathrm{~km}$ from the Paraguayan border. This region presents a subtropical climate without a dry season; the annual median temperature is about $23^{\circ} \mathrm{C}$ and the mean annual precipitation 1,300 $\mathrm{mm}$, due to a rainy season stretching from October to May. iii) Puerto Iguazú (42,000 inhabitants) located in the Northeast of the

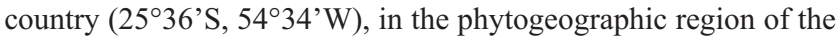
Paranaense jungle. The city is situated on the southern margin of the Iguazú River to the North and Paraná (Brazil) to the West. The climate is subtropical, with an average temperature of $22^{\circ} \mathrm{C}$ and annual rainfall of around $1,900 \mathrm{~mm}$, without a dry season. iv) Pampa del Indio (9,200 inhabitants) is located in the eastern district of the Gran Chaco Ecoregion. It generally has a temperate climate with an average temperature of about $21.8^{\circ} \mathrm{C}$. Despite being in a dry region, precipitation is significant, registering an annual average of $973 \mathrm{~mm}$.

\section{Oviposition data}

Ovitraps consisting of black plastic cups of $1,000 \mathrm{~cm}^{3}$ containing $250 \mathrm{ml}$ of water were used. An oviposition substrate in the form of a wooden tongue depressor $(15 \mathrm{~cm} \times 2 \mathrm{~cm})$ attracting the female mosquitoes was placed inside each trap. No attractant infusion was used. Oviposition substrates were replaced weekly and transported to the laboratory to count the eggs and calculate the egg index, which is the total number of eggs found over the total number of positive ovitraps (Gomes, 1998).

Table 1. Periods of monitoring of oviposition activity.

\begin{tabular}{ccc} 
Period & City & Number of ovitraps \\
2013-2016 & Tartagal & 50 \\
& Clorinda & 63 \\
& Puerto Iguazú & 30 \\
& Pampa del Indio & 20 \\
\hline
\end{tabular}


Oviposition was monitored with these ovitraps located in randomly selected houses in each of the urban areas of the four cities (Table 1). In each house, two ovitraps were installed, one inside the house and another outside in a shaded place at ground level in the backyard of each house, following WHO guidelines (WHO, 2015). The monitoring period used in this study was from August 2012 to July 2016, however only the external ovitrap data was used for this study as they would be more directly correlated with the downloaded satellite-generated environmental variables. The oviposition activity, reflected by the total number of eggs obtained from these traps, is presented in Figure 2. As can be seen, it presents the typical annual behaviour of subtropical zones. The city with the greatest oviposition activity was Puerto Iguazú and the one with the least was Pampa del Indio.

\section{Satellite-derived environmental variables}

To characterize the temporal evolution of the mosquito habitats, several satellite-derived variables were used. Vegetation conditions (humidity, temperature and precipitation) (Hay et al., 1997; Estallo et al., 2012) were monitored by the NDVI extracted from the MOD13Q1 satellite product (composed over 16 days) with a 250-meter spatial resolution (Gao, 1996; Estallo et al., 2016). The NDWI, which is related with the content of liquid water and humidity in both soil and vegetation, was also used and calculated from the same MODIS product. Gao's (1996) definition of NDWI was used and calculated using the band values provided by the MOD13Q1 product, which correspond to the middle infrared (MIR) band and near infrared band reflectance.

LST was used since it provides a good remotely sensed approximation of the environmental temperature (Wan, 1999; Peres and DaCamara, 2004; Kalluri et al., 2007). For LST, the MOD11A2 satellite product, which has a 1-kilometer resolution and is an average values of clear-sky LSTs during an 8-day period, was used. This product included one $\mathrm{LST}_{\text {day }}$ and one $\mathrm{LST}_{\text {night }}$ which in some sense represent the maximum and minimum temperatures of the 24-hour day (Wan et al., 2004). Local precipitation was obtained from the TRMM (Kummerow et al., 1998) until June 2015 at which time it was replaced by GPM (https://earthdata.nasa. gov/trmm-to-gpm) for the remainder of the study.

The NDWI, NDVI and LST (night and day) for each city were extracted as a mean of two areas of 85 ha (Estallo et al., 2008), one located within the city (the urban area) and the other covering the native vegetation surrounding the city (the rural area). All images were downloaded from the US National Aeronautics and Space Administration (NASA) website (http://e4ft101.cr.usgs.gov) and imported to GRASS 7.1 software (https://grass.osgeo.org/grass7/) to calculate the mean for each of the two areas for every date. After that, all average values, with the corresponding dates, were exported to produce a Table using R Studio software, where the final temporal series were made and the statistical model built. Taking into account that the periodicity of environmental variables and the

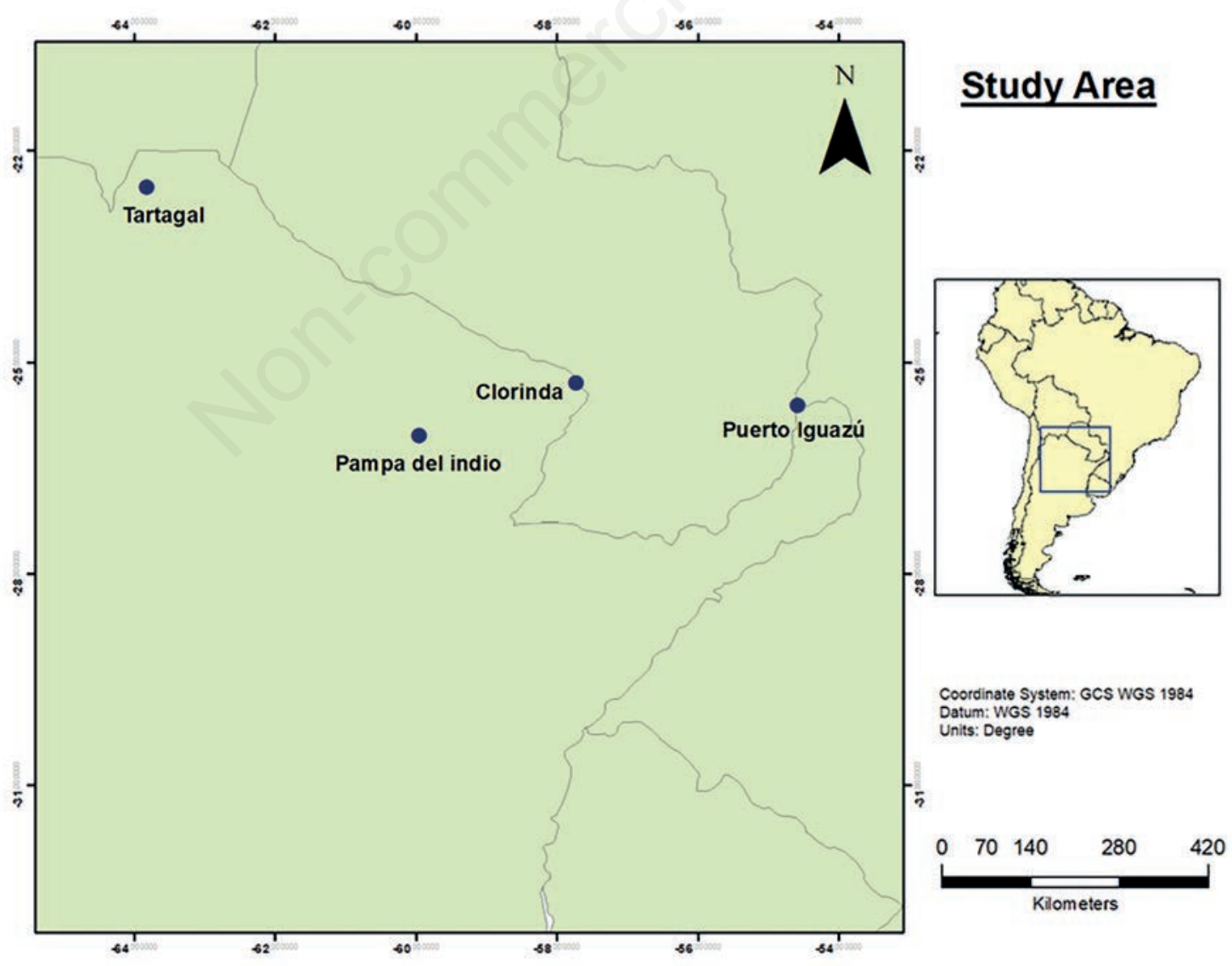

Figure 1. Study area with the four study cities. 
sampling captures were different, a lineal interpolation was performed in order to obtain values for all the sampling dates (a value for every epidemiological week). Finally, three lag functions were added from the original time series for each variable, corresponding to a one-, two- and three-week lag.

In addition, two integral variables regarding low temperatures from the previous year with a threshold of $10^{\circ} \mathrm{C}$ were incorporated into the model as it could theoretically play a role for the following summer's mosquito populations. The first variable, named weeks, was obtained by counting the number of weeks under this threshold in one epidemiological year (August-July). The second, called degrees, gave the number of degrees under the $10^{\circ} \mathrm{C}$ threshold for each week considered in the weeks variable (Gómez-Bravo et al., 2017; German et al., 2018). The procedure to generate the time series in the context of the complete system according to Porcasi et al. (2012) is schematized in Figure 3.

\section{Modelling}

As a first step, four models were created, one for each city. From the original 41 environmental satellite-derived variables (German et al., 2018) taking into account the correlation with the oviposition time series and the co-linearity between them, a subset of 11 variables were retained for the modelling: i) NDVI rural lag1; ii) NDVI urban lag-1; iii) NDWI rural lag-1; iv) NDWI urban lag-1; v) $\mathrm{LST}_{\text {day }}$ rural lag-3; vi) $\mathrm{LST}_{\text {day }}$ urban lag-3; vii) $\mathrm{LST}_{\text {night }}$ rural lag-1; viii) $\mathrm{LST}_{\text {night }}$ urban lag-2; ix) TRMM rural lag-3; $\mathrm{x}$ ) Weeks (Number of weeks under the $10^{\circ} \mathrm{C}$ threshold in rural areas); xi) Degrees (Number of degrees under $10^{\circ} \mathrm{C}$ threshold in rural areas).Based on previous experience with modelling epidemiological issues with environment remotely sensed variables (Andreo et al., 2009; Rai et al., 2012; Estallo et al., 2016), linear regression modelling was used to develop different multiple linear models. For each city, a first model was developed. Then, the first 10 sampling dates with the most error were removed and a new model created (German et al., 2018). Errors were calculated using the R package ( $\mathrm{R}$ Core Team, 2014) for plotting model results. Specifically, we checked nonlinear patterns plotting residual errors over fitted values. Then, to assess if residuals were normally distributed, a Q-Q pplot (https://www.rdocumentation.org/ pack-
ages/car/versions/3.0-0/topics/qqPlot) was made. Finally, a spread location plot was made to assess if residuals were spread equally along the predictor ranges, and checked for homoscedasticity (i.e. if they all had the same finite variance). The four models, one for each city, were obtained by the following e:

Oviposition $=\beta_{m}+\sum$ Coef $_{v} \times$ EnvironmentalVariable

Eq. 1

where $\beta_{m}$ represents the value of intercept of the model and Coef the coefficient for each satellite-derived environmental variable.

\section{Results}

\section{Individual models}

Table 2 summarizes each model and Figure 4 shows the results of the predicted values of each model and the oviposition activity

Ovipositions: Period August 2013 - July 2016

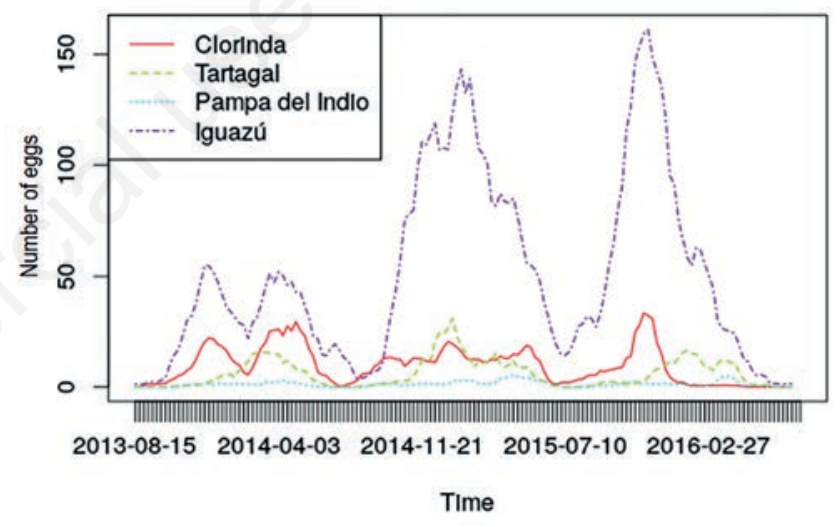

Figure 2. Oviposition activity based on external traps in the four study cities.

Table 2. Model summary.

\begin{tabular}{|c|c|c|c|c|c|c|c|c|c|c|}
\hline \multirow{2}{*}{$\begin{array}{l}\text { Performance } \\
\text { Coefficient }\end{array}$} & $\begin{array}{l}\text { Adju: } \\
\text { P-val }\end{array}$ & $\begin{array}{l}R^{2}=0.429 \\
<2.2 \mathrm{e}-16\end{array}$ & \multicolumn{2}{|c|}{$\begin{array}{l}\text { Tartagal } \\
\text { model }(M-1) \\
\text { Adjust } \mathrm{R}^{2}=0.691 \\
\text { P-value }<2.2 \mathrm{e}-16\end{array}$} & \multicolumn{2}{|c|}{$\begin{array}{l}\text { Pampa del Indio } \\
\text { model }(\mathrm{M}-2) \\
\text { Adjust } \mathrm{R}^{2}=0.63 \\
\text { P-value }<2.2 \mathrm{e}-16\end{array}$} & \multicolumn{2}{|c|}{$\begin{array}{l}\text { Clorinda } \\
\text { model (M-3) } \\
\text { Adjust } \mathrm{R}^{2}=0.589 \\
\text { P-value }<2.2 \mathrm{e}-16\end{array}$} & \multicolumn{2}{|c|}{$\begin{array}{c}\text { Puerto Iguazú } \\
\text { model (M-4) } \\
\text { Adjust } \mathrm{R}^{2}=0.686 \\
\text { P-value }<2.2 \mathrm{e}-16\end{array}$} \\
\hline & Estimate & P-value & Estimate & P-value & Estimate & P-value & Estimate & P-value & Estimate & P-value \\
\hline Intercept & -188.9 & 0.01881 & -167.500 & $2.89 \mathrm{e}-05$ & -19.77 & $5.40 \mathrm{e}-06$ & -179.300 & $7.36 \mathrm{e}-05$ & -1412.0 & $2.10 \mathrm{e}-07$ \\
\hline NDVI, rural lagl & 213.3 & $1.82 \mathrm{e}-15$ & -14.820 & 0.160250 & -14.71 & 0.00131 & 49.490 & 0.03509 & -92.48 & 0.6957 \\
\hline NDVI, urban lagl & -207.3 & 0.00012 & -25.620 & 0.286829 & 10.32 & 0.02474 & 53.420 & 0.16746 & -174.0 & 0.2539 \\
\hline NDWI, rural lag1 & -50.53 & 0.01190 & 33.420 & $3.57 \mathrm{e}-05$ & 13.03 & $3.58 \mathrm{e}-05$ & -17.480 & 0.18631 & 238.5 & 0.0722 \\
\hline NDWI, urban lagl & 99.33 & 0.01687 & 5.319 & 0.714602 & -7.47 & 0.04359 & 90.180 & 0.02820 & 157.1 & 0.0970 \\
\hline Weeks $\left(<10^{\circ} \mathrm{C}\right)$ & -8.904 & $<2.2 \mathrm{e}-16$ & -1.187 & 0.010635 & -0.17 & 0.01717 & 6.278 & $1.03 \mathrm{e}-08$ & 9.04 & 0.3673 \\
\hline Degrees $\left(<10^{\circ} \mathrm{C}\right)$ & 1.459 & 0.0000574 & -0.634 & $1.79 \mathrm{e}-06$ & 0.04 & 0.02617 & -2.165 & 0.00303 & 1.652 & 0.6381 \\
\hline $\mathrm{LST}_{\text {day, }}$ rural lag3 & 2.462 & 0.01098 & -1.266 & 0.000164 & 0.1291 & 0.25206 & 2.229 & $1.66 \mathrm{e}-07$ & 4.915 & 0.0482 \\
\hline $\mathrm{LST}_{\mathrm{day}}$, urban lag3 & -0.1695 & 0.86580 & 1.585 & $8.87 \mathrm{e}-06$ & -0.1008 & 0.35587 & -1.027 & 0.01875 & 0.53 & 0.8088 \\
\hline $\mathrm{LST}_{\text {night }}$, rural lagl & -1.752 & 0.04635 & 0.799 & 0.027233 & 0.0425 & 0.32717 & 1.919 & $1.98 \mathrm{e}-06$ & 2.81 & 0.2818 \\
\hline $\mathrm{LST}_{\text {night }}$, urban lag2 & -0.06599 & 0.94097 & -0.517 & 0.150376 & 0.008121 & 0.86860 & -2.724 & $2.33 \mathrm{e}-08$ & -3.62 & 0.1866 \\
\hline TRMM, rural lag3 & -0.03514 & $5.55 \mathrm{e}-13$ & 0.007 & 0.571708 & 0.001196 & 0.00173 & 0.803 & 0.73708 & 0.062 & $1.27 \mathrm{e}-11$ \\
\hline
\end{tabular}

NDVI, normalized difference vegetation index; NDWI, normalized difference water index; LST, land surface temperature; TRMM, Tropical Rainfall Measuring Mission. 


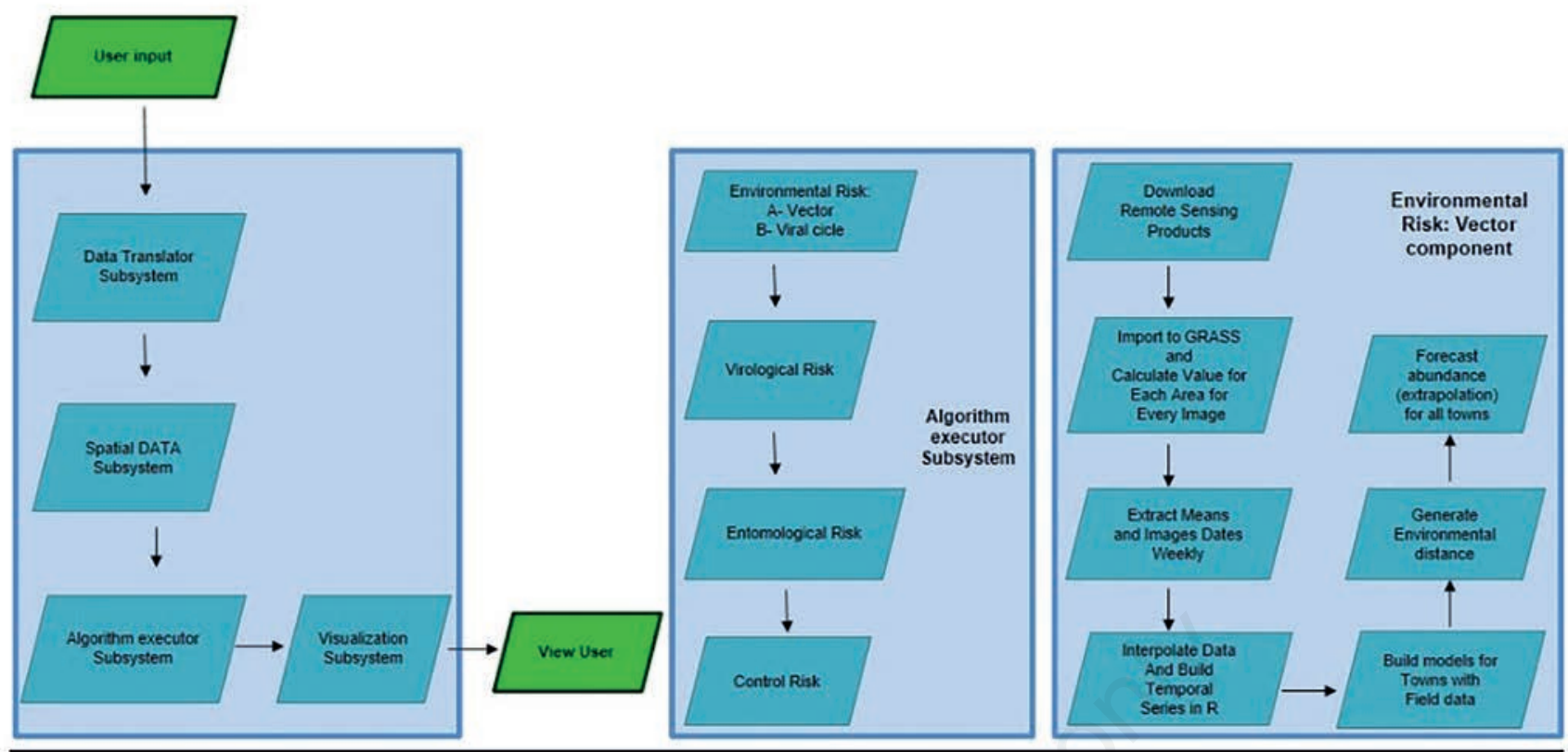

Figure 3. Processing procedure architecture.

A

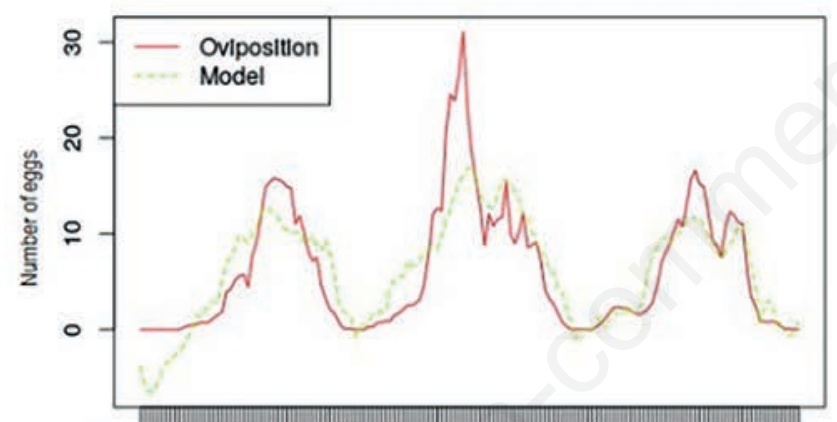

2013-08-01 2014-03-20 2014-11-07 2015-06-26 2016-02-13

Time

Clorinda

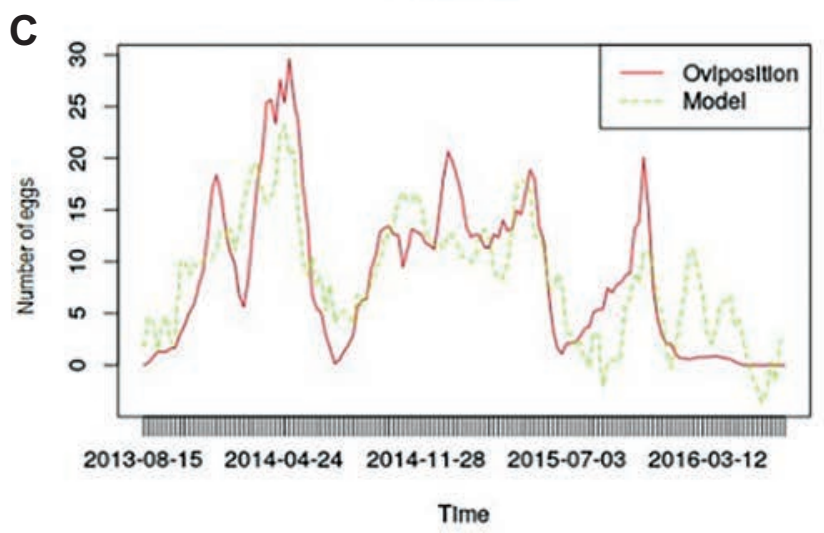

B

Pampa del Indio

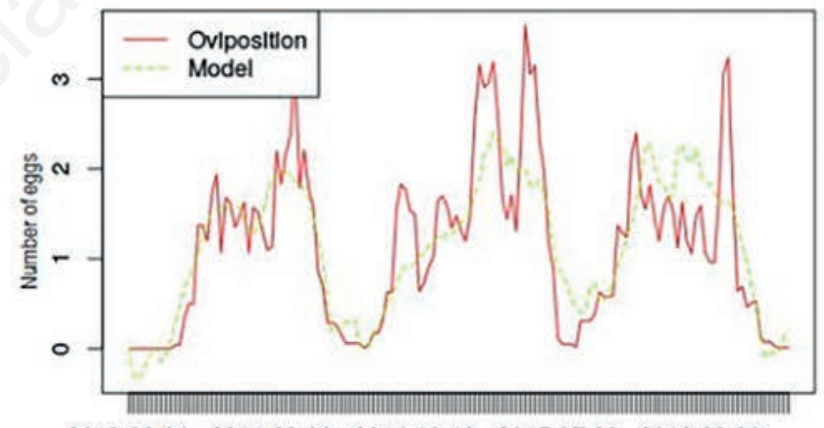

2013-08-01 2014-03-06 2014-10-10 2015-07-03 2016-02-06

TIme

Puerto Iguazú

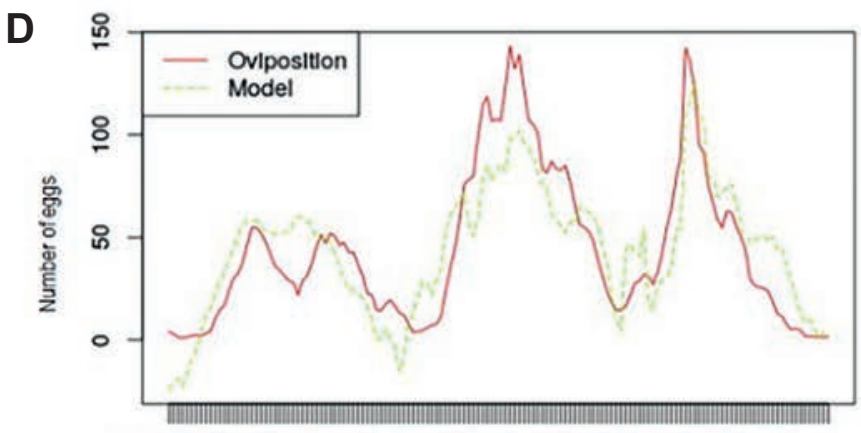

2013-08-01 2014-03-06 2014-10-10 2015-06-05 2016-02-27

Time

Figure 4. Oviposition activity of each city: fitted values for each model. (A) Tartagal model (M-1); (B) Pampa del Indio model (M-2); (C) Clorinda model (M-3); (D) Puerto Iguazú model (M-4). 
in each city. In general, predicted values were similar to the ones sampled and the models followed the annual mosquito behaviour in the four cities.

Then, as shown in Figure 5, the capacity of each model to explain the oviposition activity in the other three cities was assessed: the model of each city was tested with the environmental data of the other three cities and then the result of the models was compared to the real oviposition situation. These model turned out to be very different from each other. Each model conformed to the particular environmental characteristics of each city and therefore not capable to describe the oviposition in the other cities (as they have different environmental characteristics).

\section{Model generalization efforts}

Because the four models created are very different from each other, in a second step, a global model using the dataset from the four cities was generated in the same manner as before. This global model has greater flexibility and its capability to adapt to the different environmental characteristics of the study area was explored. A summary of the model is detailed in Table 2 and the results presented in Figure 6. As shown, the performance of this global model did not improve but resulted in an even poorer pic- ture than the individual ones. It should be mentioned that the model presented a similar annual decrease and increase in oviposition in Clorinda; however, the predicted values did not generally represent the values sampled. In other words, the model did not show the same annual oviposition behaviour.

\section{Further development operational approach}

Some more sophisticated modelling techniques are being evaluated (Scavuzzo et al., 2018), but they are not mature enough for an operational implementation. In the section below some further developments are discussed.

\section{Environmental distance}

Given that the four models for each city were not interchangeable and that the global model did not fit all four cities, this section details the methodology adopted to establish an approximate model that could be used for any other town in the North of Argentina.

The simplest way to interpolate a known variable with consideration to others is nearest-neighbour interpolation (also known as proximal interpolation). This method determines the closest neighbouring pixel known and assumes the variable value of it rather
A

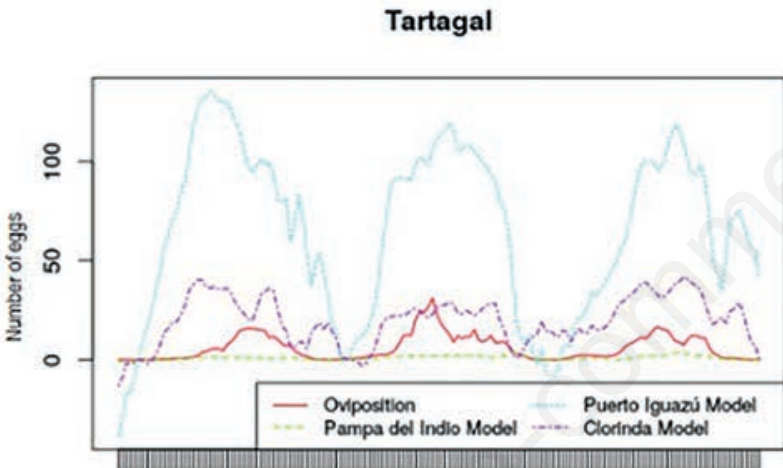

2013-08-01 2014-03-20 2014-11-07 2015-06-26 2016-02-13

Time

C

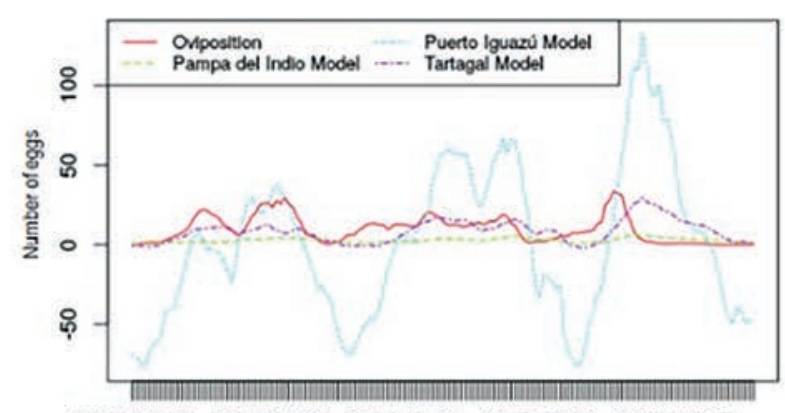

2013-08-15 2014-04-03 2014-11-21 2015-07-10 2016-02-27

Time
B

Pampa del Indio

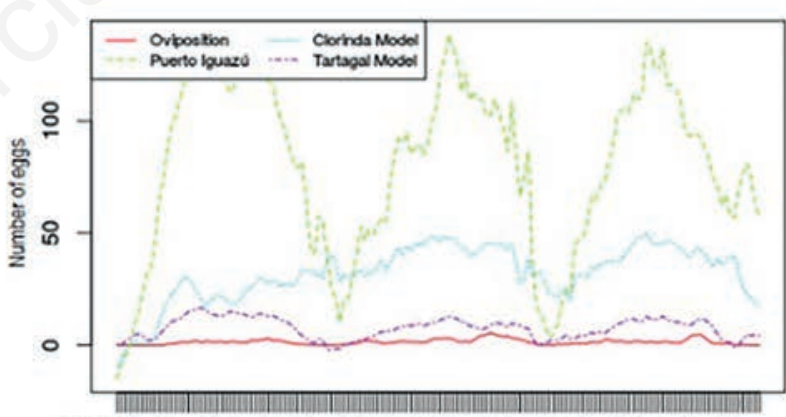

2013-08-01 2014-03-20 2014-11-07 2015-06-26 2016-02-13

TIme

D

Puerto Iguazú

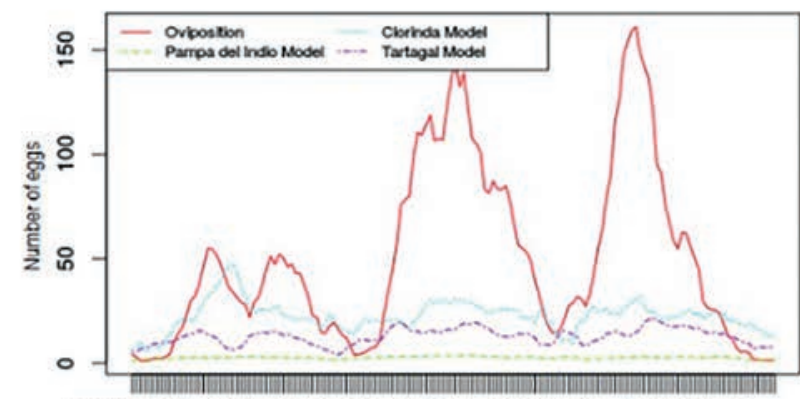

2013-08-01 2014-03-20 2014-11-07 2015-06-26 2016-02-13

TIme

Figure 5. Oviposition activity over fitted values for each model. (A) Tartagal over fitted values of M-2, M-3 and M-4; (B) Pampa del Indio over fitted values of M-1, M-3 and M-4; (C) Clorinda over fitted values of M-1, M-2 and M-4; (D) Puerto Iguazú over fitted values of M-1, M-2 and M-3. 
than calculate an average value by some weighting criteria or generating an intermediate value based on complicated rules. For our particular problem, given our known four developed models M-1, M-2, M-3, M-4, this means that for an additional point/town localized at position $\mathrm{X}$, we can set model $\mathrm{M}_{(\mathrm{X})}$ equal to the known model of the nearest city (nearest neighbour approach), i.e. $\mathrm{M}_{(\mathrm{X})}=$ $\mathrm{M}_{j}$ where $j$ corresponds to the nearest town with $j=1,4$.

An improvement on this approach would be to use an average of the four known models weighted by the inverse of the distance of this new point to each of the cities where we have a model. That is, the model of the nearest city will have a stronger weight and the model that is farther away would have a lower weight, using the following formula:

$$
M_{(x)}=\sum M_{j} / L_{j}
$$

Eq. 2

where $L_{j}$ represents the normalized distance from the city $j$ to $x$ (the geographic localization of the new town). The problem with the previous idea is that it is more reasonable to think that the vector behaviour in a town at point $x$ would be more comparable to the city that is environmentally more similar and not necessarily the one that is closer. In that sense (in the scheme of nearest neighbour), the model for city $j$ should be used if it were more environmentally similar to the town located at $x$. Closer usually means geographically closer, but we can now think of it in the environmental sense (i.e. more similar environmental variables) which naturally leads to the Normalized Environmental Distance concept.

In order to apply these ideas, which ecologically and biologically sound reasonable, we would need to define the variables involved in the concept environmental similarity and then define an operational environmental distance. For our case we used the 19 WorldClim given by Hijmans et al. (2005) from a large time series and in addition altitude (ALT) and a mean value for NDVI for a 10year period. Once the variables are defined, we can define a generalized distance based on these environmental variables as follows:

$$
\operatorname{Dist}_{\left(x_{1}-x_{2}\right)}=\sqrt{\left(\sum\left(v i_{1}-v i_{2}\right)^{2}\right)}
$$

where $v i$ is each of 19 bioclimatic variables plus ALT and NDVI. It should be clear that, to compute the sum of equation 3 , the variables
A
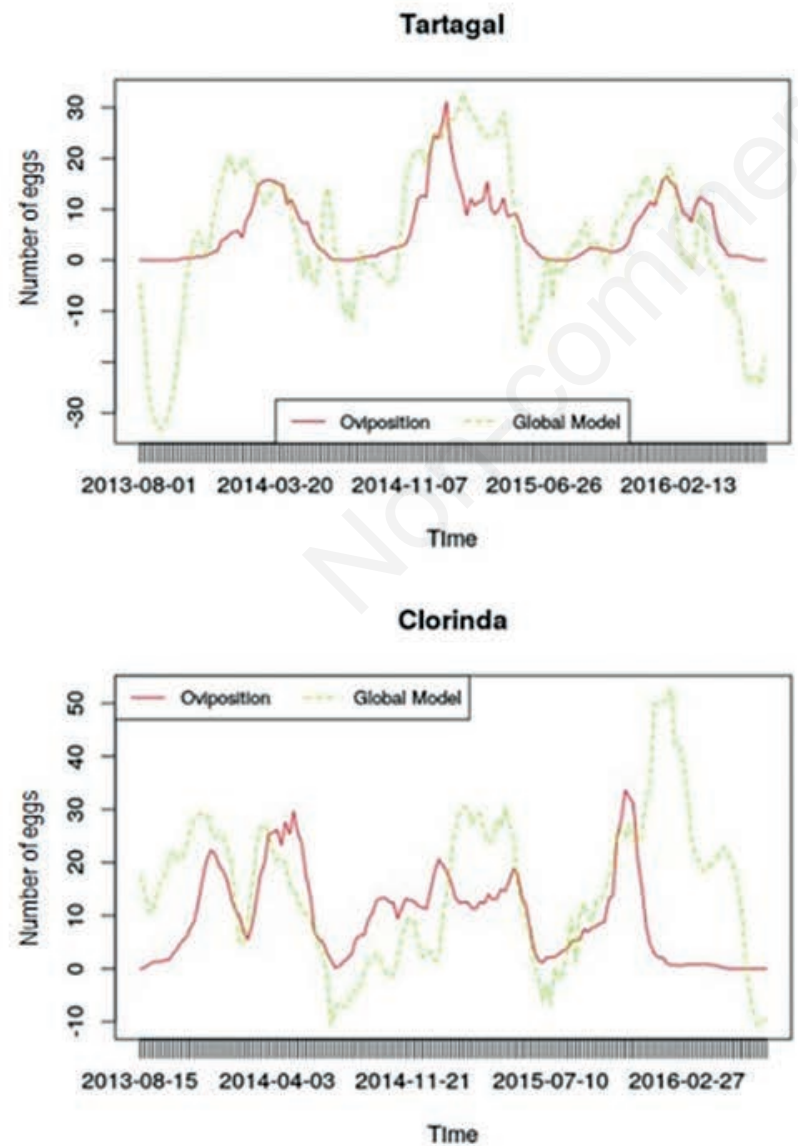

B

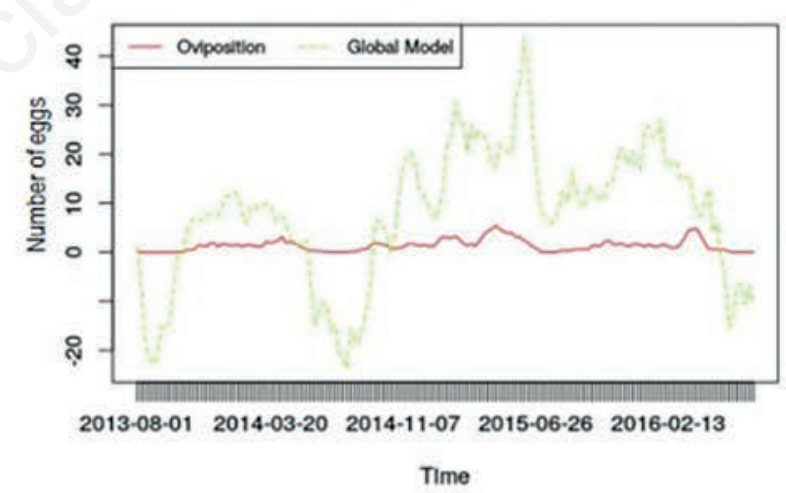

D

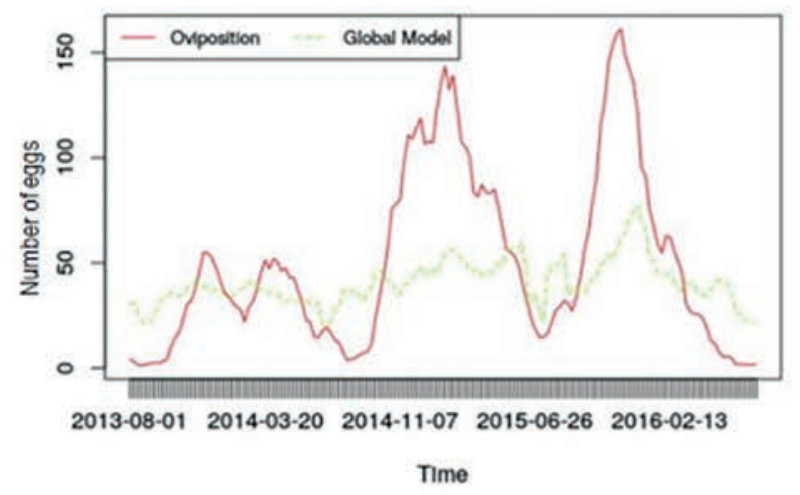

Figure 6. Fitted values of the Global model over oviposition activity in each city. (A) Tartagal model (M-1); (B) Pampa del Indio model (M-2); (C) Clorinda model (M-3); (D) Puerto Iguazú model (M-4). 
must be previously standardized and dimensionless (it is possible to do that, simply dividing the original value of each environmental variable by their maximum value). Subsequently, we can estimate the environmental distance from each city with location $x$ and our four modelled cities $j s$, and recalculate the extrapolation method by Eq. 2 but now using the environmental distance. Operatively, to calculate the distances, we need to define a buffer region of $20 \mathrm{~km}$ around each $j$ city to characterize the variables of these cities (as a mean of the pixels into the buffer) and use the probabilities class membership of ENVI software (http://www.sigsa.info/ productos/envi) to calculate the normalized environmental distance from each pixel to each of the four modelled cities. The result of the normalized environmental distance for each city is presented in Figure 7. It's important to note that the normalized environmental distance tells us how similar a city is compared to the other three. Pixels with values close to 1 means that it is more similar to the city compared. As an example of how this methodology works, the normalized distance of Tucuman, Santiago del Estero, Corrientes and Salta are described on Table 3. With these distances calculated, an oviposition estimation on each new town can be calculated, for a given week, using M1 to M4, weighted by $1 / \mathrm{Lj}$ but using the envi- ronmental variables $V i$ in all the cases of this new town for this specific week. The results of oviposition for the week 2014-02-06 in the four new cities are described in Figure 8. It should be clear that this does not represent a validation of the proposed method. It can only be validated when additional and independent field data are available. So, here we can only say that the proposed environmental interpolation method is novel, easily implementable and ecologically and mathematically consistent.

Table 3. Normalized Environmental Distance to the four models.

\begin{tabular}{lcccc}
\multicolumn{2}{c}{$\begin{array}{c}\text { Inverse of the Normalized Environmental Distance } \\
\text { Puerto } \\
\text { Iguavá }\end{array}$} & $\begin{array}{c}\text { Clorinda } \\
\text { Pampa } \\
\text { del Indio }\end{array}$ & Tartagal \\
Tucumán & 0.197 & 0.011 & 0.388 & 0.402 \\
Santiago del Estero & 0.098 & 0.009 & 0.576 & 0.315 \\
\hline Corrientes & 0.491 & 0.466 & 0.039 & 0.002 \\
Salta & 0.112 & 0.005 & 0.133 & 0.749 \\
\hline
\end{tabular}

\section{B}

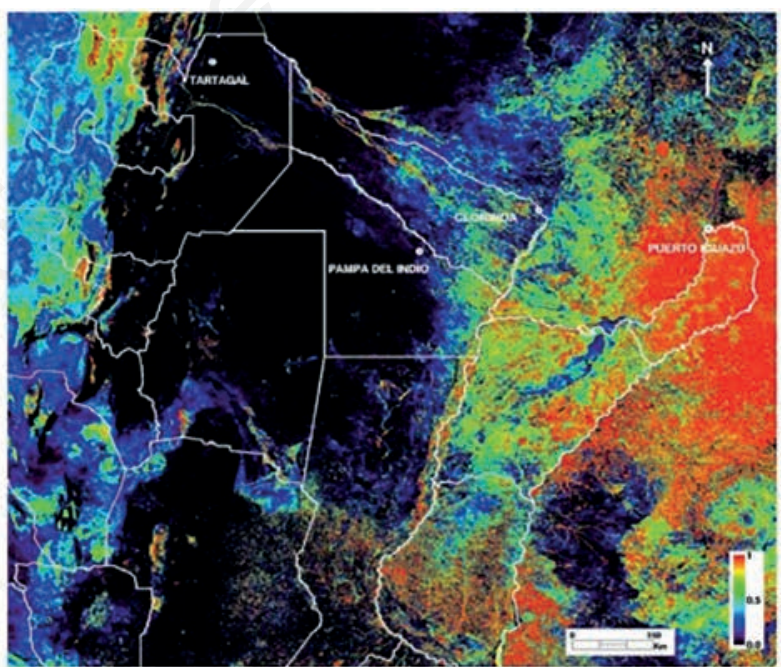

C

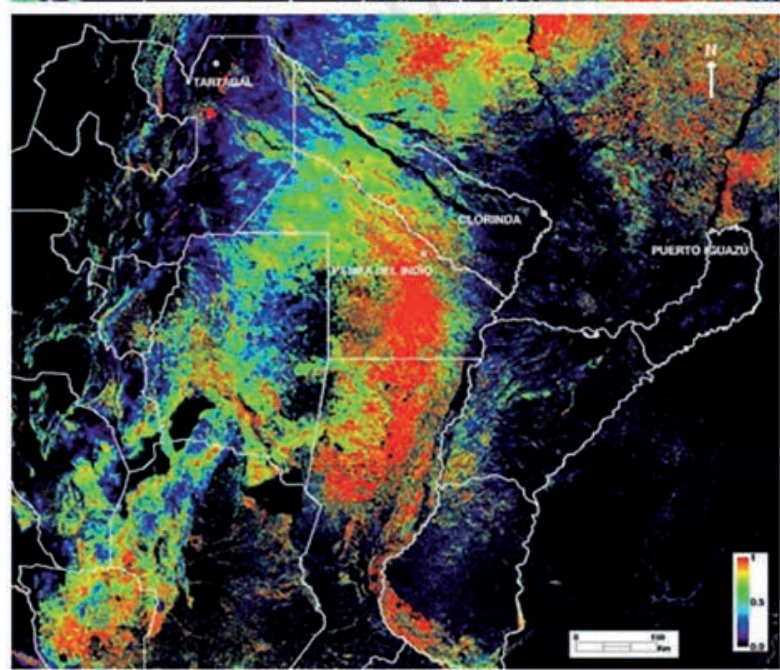

D

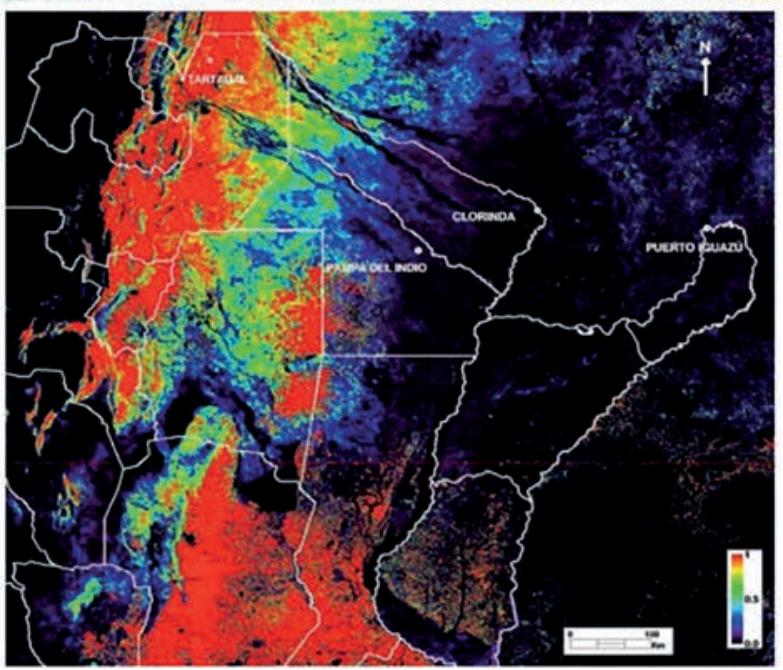

Figure 7. Inverse of the Normalized Environmental Distance map (or environmental similarity map). (A) (1/L) To Clorinda; (B) (1/L) To Puerto Iguazú; (C) (1/L) To Pampa del Indio; (D) (1/L) To Tartagal. 


\section{Discussion and Conclusions}

This study represents an upgrade of the National Operational Risk System (Porcasi et al., 2012) that is being used in Argentina to allow health decision makers to perform oriented control actions, using a complete set of satellite-derived variables. The methodology we describe herein is based on completely free software and free and globally available space data in order to assure its replication in different endemic regions on the world.

Since the pioneer work of Rogers (1991), Hay (2000), Beck et al. (2000), Gorla (2002), Tran et al. (2004) and Ostfeld et al. (2005), much has been done on the use of remote sensing in epidemiology, especially with regard to vector-borne diseases (Scavuzzo et al., 2018). Despite this, there are very few examples where geospatial technology is used operationally in the national health systems. There is some more evidence on the use of GIS tools for this purpose but very few environmental products derived from remote sensors are used (Rotela et al., 2017; Porcasi et al., 2012). As Yang et al. (2012) stated, the delay in the response and the use of expensive software are the principal barriers for an operational GIS-based early warning system in epidemiology. The use of open-source technologies and free operational and globally available satellite data are therefore the key to guarantee timeliness and affordability.

A conceptual difference between academic study and operative development is that the former starts with the formulation of a scientific hypothesis, while the latter begins with the generation of user requirements that should be translated into system requirements. The contribution of the model presented herein could generate improvements on the national system already in place (Porcasi et al., 2012) by fulfilling the following requirements: i) estimate the risk stratification by applying a multifactor approach at the national level for all the localities; ii) facilitate decision making; iii) update environmental conditions based on remotely sensed data; iv) be expandable in order to cover others regional countries without major changes through the use of a modular concept.

The modular design of the informatics platform allows us to improve the environmental component by introducing a dynamic forecasting of the vector for each town based on oviposition temporal evolution. The system architecture implemented also permits its application of risk mapping to others vector-borne diseases. In China, Yang et al. (2012) developed a similar platform for monitoring schistosomiasis transmission. This contribution represents an improvement of the national system model that has been running since 2011.

This upgrade is related only with the national scale of the system, since decision makers at the national level need a general framework specifically to define the allocation of the economic resources that need to be distributed between the different localities. In general, the algorithm developed drastically improves the temporal resolution of the risk prediction. While the original platform was updated twice a year, this new version is calculated weekly by combining landscape epidemiology concepts and previous data on vector-borne diseases, in this case dengue, supported by research experience in Latin America and new evidence (Porcasi et al., 2005; Porcasi et al., 2006; Salomón et al., 2006; Rotela et al., 2007; Rotela et al., 2010; Khormi et al., 2011).

Satellite-derived environmental variables were used to build temporal models to predict the oviposition activity in four cities in northern Argentina. It was shown that these variables were good predictors of the conditions in the environment (temperature, humidity and precipitation) which influenced oviposition activity. Also, different time-lagged variables were important and justified their inclusion because for some of the variables, the highest correlation was found even with three time lags $\left(\mathrm{LST}_{\text {day }}\right)$. Moreover, the inclusion of lagged variables is positive from the point of view of forecast. In addition, integral variables were calculated to be used in the model so as to include the low temperature conditions

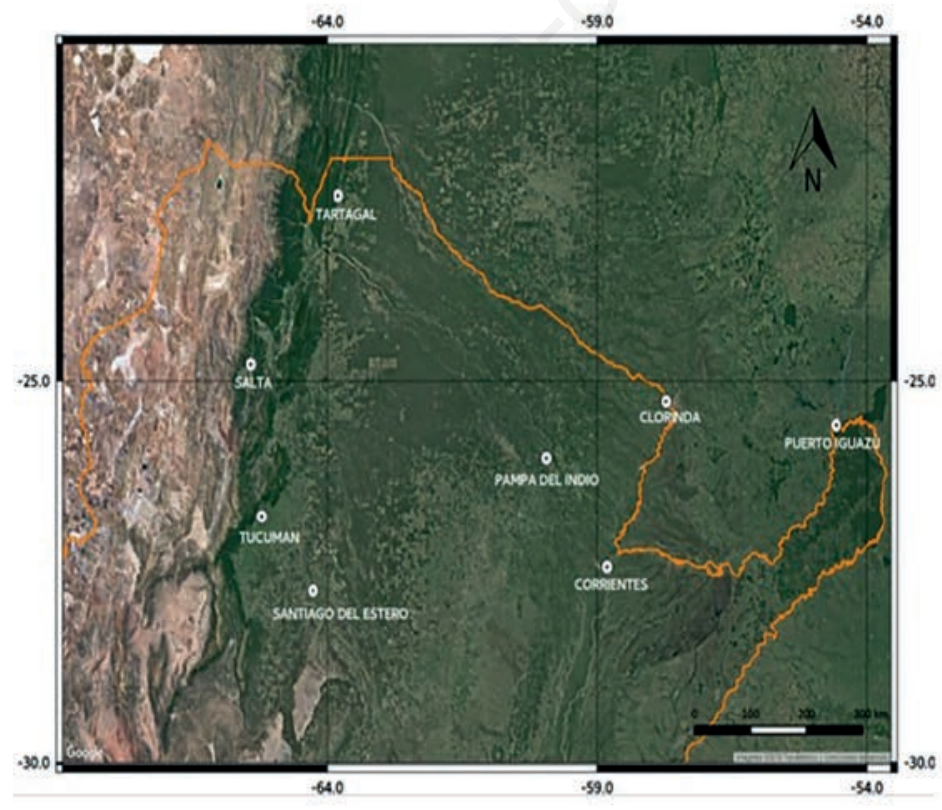

Oviposition activity week 2014-02-06

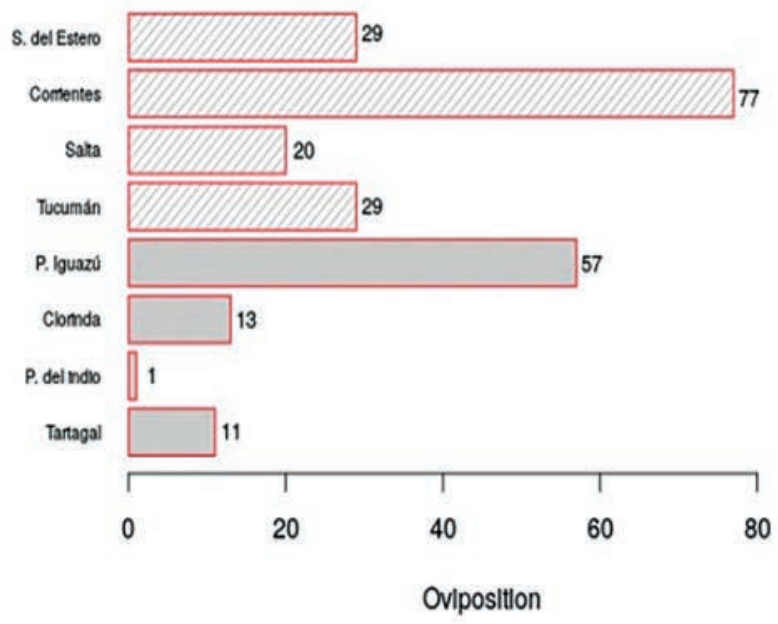

Figure 8. Oviposition activity results for week of 2014-02-06. 
for long periods previous to the oviposition sampling week.

The individual models M-1 $\left(\mathrm{R}^{2}=0.69\right), \mathrm{M}-2\left(\mathrm{R}^{2}=0.63\right), \mathrm{M}-3$ $\left(\mathrm{R}^{2}=0.58\right)$ and $\mathrm{M}-4\left(\mathrm{R}^{2}=0.68\right)$, are an improvement of previous studies (Estallo et al., 2008; Estallo et al., 2012; Estallo et al., 2016), because the long-term data used are more adequate for obtaining a more general model and not so specific of the local conditions. Another advantage is the use of a more complete set of remotely sensed variables which are all operatively accessible. This last advantage is very important and in line with our institutional objective, which is to generate forecast modelling for every location in the northern region of Argentina, in that way it is an upgrade of Argentina's National Risk System (Porcasi et al., 2012).

Furthermore, the methodology presented herein could be used as a base for the automation of the procedure for creating the satellite derived variables and modelling results. This is why all the information processing steps of were based on open-source programming languages (Grass and $\mathrm{R}$ ) in order to be able to reproduce them elsewhere in a common format and in a short time period. Clearly, an automatic computational procedure is essential to produce a national operational framework for the future, which requires working with large amounts of data (big data).

In order to reach the objective of the study, an innovative procedure was used to generalize the four individual models so that the final product could be widely used. This procedure is based on a biological approach and it consists of an interpolation based on the environmental distance or environmental similitude calculated from historic climatic and vegetation conditions. This concept refers to how similar (from an environmental point of view) one place is with respect to another, regardless of the geographical distance between the two places (Hirzel and Arlettaz, 2003; Díaz Villanueva et al., 2018). In a way, this approach resembles the concept of ecomorphology, that is, the relationship between the ecological role of an individual and its morphological adaptations (Leisler and Winkler, 1985). This can also be seen from a convergent evolution perspective, where ecologically similar but geographically distant communities develop similar morphological features, which appear independently in species of different lineages (Wainwright and Reilly, 1994; Fernandez et al., 2012). Both of these concepts point to the importance of the environment regardless of distance. Therefore, the approach proposed in this paper, supposes the application of an ecological concept to a mathematical model. There is no previous use of this concept for this purpose in the literature but we believe it is valid since the platform serves to model a biological phenomenon based basically on ecoepidemiology ideas.

It would be important, in a second stage, to evaluate the effectiveness of the method developed herein, as well as its limitations. Since this platform is based on the interpolation methodology, conceptually solid, it would not require undergoing a validation process. However, the performance of this method would be improved by incorporating new city models, since new ecosystems could be defined, such as distance classes. Therefore, it is necessary to evaluate how many models will be needed to achieve an optimal oviposition activity prediction of the vector.

Finally, it is also important to emphasize that the main public health strategies for the prevention of dengue, chikungunya and zika lies in Ae. aegypti population control. Therefore, having a flexible system that provides timely information on the dynamics of the population of the vector would not only favour the planning of preventive actions, but also achieve greater efficiency and effec- tiveness of them. Thus, the upgrade presented in this paper is a simple, novel and accessible way to predict the dynamics of the vector in a weekly period. As a next step, we are planning the incorporation of data from more cities in the region, in order to improve the accuracy of the system.

\section{References}

Andreo V, Provensal C, Scavuzzo M, Lamfri M, Polop J, 2009. Environmental factors and population fluctuations of Akodon azarae (Muridae: Sigmodontinae) in central Argentina. Austral Ecol 34:132-42.

Arboleda S, Jaramillo N, Peterson AT, 2009. Mapping environmental dimensions of dengue fever transmission risk in the Aburrá Valley, Colombia. Int J Envron Res Public Health 6:3040-55.

Beck LR, Lobitz BM, Wood BL, 2000. Remote sensing and human health: new sensors and new opportunities. Emerg Infect Dis 6:217-27.

Butt B, Turner WD, Singh A, Brottem L, 2011. Use of MODIS NDVI to evaluate changing latitudinal gradients of rangeland phenology in Sudano-Sahelian West Africa. Remote Sensing Environ 115:3367-76.

Christophers SR, 1960. Aedes aegypti (L.): The Yellow Fever Mosquito. Cambridge, UK: Cambridge University Press.

Díaz Villanueva V, Mariluan G, Albariño R, 2018. Disturbance disrupts the relation between community similarity and environmental distance at small spatial scale. Ecol Res 33:225-36.

Eisen L, Monaghan AJ, Lozano-Fuentes S, Steinhoff DF, Hayden $\mathrm{MH}$, Bieringer PE, 2014. The impact of temperature on the bionomics of Aedes (Stegomyia) aegypti, with special reference to the cool geographic range margins. J Med Entomol 51:496-516.

Espinosa M, Weinberg D, Rotela CH, Polop F, Abril M, Scavuzzo CM, 2016a. Temporal dynamics and spatial patterns of Aedes aegypti breeding sites, in the context of a dengue control program in Tartagal (Salta province, Argentina). PLoS Negl Trop Dis 10:e004621.

Espinosa MO, Polop F, Rotela CH, Abril M, Scavuzzo CM, 2016 b. Spatial pattern evolution of Aedes aegypti breeding sites in an Argentinean city without a dengue vector control programme. Geospat Health 11:307-17.

Estallo EL, Lamfri MA, Scavuzzo CM, Almeida FFL, Introini MV, Zaidenberg M, Almirón WR, 2008. Models for predicting Aedes aegypti larval indices based on satellite images and climatic variables. J Am Mosq Control Assoc 24:368-76.

Estallo EL, Ludueña-Almeida FF, Visintin AM, Scavuzzo CM, Introini MV, Zaidenberg M, Almirón WR, 2011. Prevention of dengue outbreaks through aedes aegypti oviposition activity forecasting method. Vector-Borne Zoonotic Dis 11:543-9.

Estallo EL, Ludueña-Almeida FF, Visintin AM, Scavuzzo CM, Lamfri MA, Introini MV, Zaidenberg M, Almirón WR, 2012. Effectiveness of normalized difference water index in modelling Aedes aegypti house index. Int J Remote Sens 33:425465.

Estallo EL, Ludueña-Almeida FF, Introini MV, Zaidenberg M, Almirón WR, 2015. Weather variability associated with Aedes (Stegomyia) aegypti (Dengue vector) oviposition dynamics in Northwestern Argentina. PLoS ONE 10:e0127820.

Estallo EL, Benitez EM, Lanfri MA, Scavuzzo CM, Almirón WR, 
2016. MODIS Environmental Data to Assess Chikungunya, Dengue, and Zika Diseases Through Aedes (Stegomia) aegypti Oviposition Activity Estimation. IEEE J Select Topics Appl Earth Observ Remote Sens 9:5461-6.

Fernández EM, Ferriz RA, Bentos CA, López GR, 2012. Dieta y ecomorfología de la ictiofauna del arroyo Manantiales, provincia de Buenos Aires, Argentina. Rev Museo Argentino Ciencias Natural 14:1-13. Available from: http://www. scielo.org.ar/scielo.php?script=sci_arttext\&pid=S185304002012000100001\&lng=es\&tlng=es Accessed: January 6, 2018.

Focks DA, Haile DG, Daniels E, Mount GA, 1993a. Dynamic life table model for Aedes aegypti (Diptera: Culcidae). Analysis of the literature and model development. J Med Entomol 30:1003-17.

Focks DA, Haile DG, Daniels E, Mount GA, 1993b. Dynamiclife table model for Aedes aegypti (Diptera: Culicidae): simulation and validation. J Med Entomol 30:1018-28.

Gao B, 1996. NDWI - A normalized difference water index for remote sensing of vegetation liquid water from space. Remote Sens Environ 58:257-66.

German A, Espinosa MO, Abril M, Scavuzzo CM, 2018. Exploring Satellite Based temporal forecast modelling of Aedes aegypti oviposition from an operational perspective. Remote Sens Appl: Soc Environ 11:231-40.

Gomes AC, 1998. Medidas dos niveis de infestacao urbana para aedes (stegomyia) aegypti e aedes (stegomyia) albopictus em Programa de Vigilancia Entomológica. Inf Epidemiol Sus 7:49-57.

Gómez-Bravo A, German A, Abril M, Scavuzzo M, Salomón OD, 2017. Spatial population dynamics and temporal analysis of the distribution of Lutzomyia longipalpis (Lutz \& Neiva, 1912) (Diptera:Psychodidae: Phlebotominae) in the city of Clorinda, Formosa, Argentina. Paras Vect 10:352.

Gorla DE, 2002. Remotely sensed environmental variables as indicators of Triatoma infestans (Heteroptera: Reduviidae) distribution. Variables ambientales registradas por sensores remotos como indicadores de la distribución geográfica de Triatoma infestans (Heteroptera: Reduviidae). Ecol Austral 12:117-27.

Gu Y, Brown JF, Verdin JP, Wardlow B. 2007. A five-year analysis of MODIS NDVI and NDWI for grasslanddrought assessment over the central Great Plains of the United States. Geophys Res Lett 34:1-6.

Hay SI, Packer MJ, Rogers DJ, 1997. The impact of remote sensing on the study and control of invertebrate intermediate host and vectors for disease. Remote Sens Environ 18:2899-30.

Hay SI, 2000. An overview of remote sensing and geodesy for epidemiology and public health application. Adv Parasitol 47:135.

Hijmans RJ, Cameron SE, Parra JL, Jones PG, Jarvis A, 2005. Very high resolution interpolated climate surfaces for global land areas. Int J Climatol 25:1965-78.

Hirzel AH, Arlettaz R, 2003. Modeling habitat suitability for complex species distributions by environmental-distance geometric mean. Environ Manag 32:614-23.

Hopp MJ, Foley JA, 2001. Global-scale relationships between climate and the dengue fever vector, Aedes aegypti. Clim Change 48:441-63.

Justice CO, Townshend JRG, Vermote EF, Masuoka E, Wolfe RE, Saleous N, Roy DP, Morisette JT, 2002. An overview of MODIS Land data processing and product status. Remote Sens
Environ 83:3-15.

Kalluri S, Gilruth P, Rogers D, Szczur M, 2007. Surveillance of arthropod vector-borne infectious diseases using remote sensing techniques: A review. Plos Pathogen 10:1361-71.

Khormi HM, Kumar L, Elzahrany RA, 2011. Modeling spatiotemporal risk changes in the incidence of dengue fever in Saudi Arabia: a geographical information system case study. Geospat Health 6:77-84.

Kummerow C, Barnes W, Kozu T, Shiue J, Simpson J, 1998. The tropical rainfall measuring mission (TRMM) sensor package. J Atmosphc Ocean Technol 15:809-17.

Lambrechts L, Paaijmans KP, Fansiri T, Carrington LB, Kramer LD, Thomas MB, Scott TW, 2011. Impact of daily temperature fluctuations on dengue virus transmission by Aedes aegypti. Proc Nation Acad Sci 108:7460-5.

Leisler B, Winkler H, 1985. Ecomorphology. In: Johnston RF, ed. Current Ornithology. Boston, MA: Springer.

Liang G, Gao X, Gould EA, 2015. Factors responsible for the emergence of arboviruses; strategies, challenges and limitations for their control. Emerg Microb Infect 4:e18.

Mordecai EA, Cohen JM, Evans MV, Gudapati P, Johnson LR, Lippi CA, Miazgowicz K, Murdock CC, Rohr JR, Ryan SJ, Savage V, Shocket MS, Stewart Ibarra A, Thomas MB, Weikel DP, 2017. Detecting the impact of temperature on transmission of Zika, dengue, and chikungunya using mechanistic models. PLoS Negl Trop Dis 11:e0005568.

Morin CW, Comrie AC, Ernst K, 2013. Climate and dengue transmission: evidence and implications. Environ Health Perspect 121:1264-72.

Morin CW, Monaghan AJ, Hayden MH, Barrera R, Ernst K, 2015. Meteorologically driven simulations of dengue epidemics in San Juan, PR. PLoS Negl Trop Dis 9:e0004002.

Ostfeld RS, Glass GE, Keesing F, 2005. Spatial epidemiology: An emerging (or re-emerging) discipline. Trends Ecol Evol 20:328-36.

Peres LF, DaCamara CC, 2004. Land surface temperature and emissivity estimation based on the two-temperature method: sensitivity analysis using simulated MSG/SEVIRI data. Remote Sens Environ 91:377-89.

Polop F, Provensal C, Scavuzzo M, Lamfri M, Calderón G, Polop J, 2008. On the relationship between the environmental history and the epidemiological situation of Argentine hemorrhagic fever. Ecol Res 23:217-25.

Porcasi X, Calderón G, Lamfri L, Polop J, Sabattini M, Scavuzzo CM, 2005. Predictive distribution maps of zoonoses reservoir rodents in a southern America. Masto Neotrop 12:199-216.

Porcasi X, Catalá SS, Hrellac H, Scavuzzo MC, Gorla DE, 2006. Infestation of rural houses by Triatoma infestans (Hemiptera: Reduviidae) in southern area of Gran Chaco in Argentina. J Med Entomol 43:1060-7.

Porcasi X, Rotela CH, Introini MV, Frutos N, Lanfri S, Peralta G, De Elia EA, Lanfri MA, Scavuzzo CM, 2012. An operative dengue risk stratification system in Argentina based on geospatial technology. Geospat Health 6:31-42.

R Core Team, 2014. R: A language and environment for statistical computing. R Foundation for Statistical Computing, Vienna, Austria. Available from: http://www.R-project.org/

Rai PK, 2012. Application of multiple linear regression model through GIS and remote sensing for malaria mapping in Varanasi District, India. Health Sci J. Available from: http://www.hsj.gr/medicine/application-of-multiple-linear- 
regression-model-through-gis-and-remote-sensing-for-malaria-mapping-in-varanasi-district-india.php?aid=3122

Ritchie SA, 1984. The production of Aedes aegypti by a weekly ovitraps survey. Mosquito News 44:77-9.

Rocchini D, Andreo V, Forster M, Garzon-Lopez CX, Gutierrez AP, Gillespie TW, Hauffe HC, He KS, Kleinschmit B, Mairota P, Marcantonio M, Metz M, Nagendra H, Pareeth S, Ponti L, Ricotta C, Rizzoli A, Schaab G, Zebisch M, Zorer R, Neteler M, 2015. Potential of remote sensing to predict species invasions: A modelling perspective. Progr Phys Geogr 39:283-309.

Rogers DJ, 1991. Satellite imagery, tsetse and trypanosomiasis in Africa. Prev Vet Med 11:201-20.

Rotela CH, Fouque F, Lamfri M, Sabatier P, Introini V, Zaidenberg M, Scavuzzo CM, 2007. Space-time analysis of the dengue spreading dynamics in the 2004. Tartagal outbreak, Northern Argentina. Acta Trop 103:1-13.

Rotela CH, Espinosa MO, Albornoz C, Lafaye M, Lacaux JP, Tourre YM, Vignolles MC, Scavuzzo CM, 2010. Desarrollo de mapas predictivos de densidad focal de Aedes aegypti en la ciudad de Puerto Iguazú (Argentina), basados en información ambiental derivada de imágenes Spot 5 HRG1. Rev Selper 30.

Rotela C, Lopez L, Frías Céspedes M, Barbas G, Lighezzolo A, Porcasi X, Lanfri MA, Scavuzzo CM, Gorla DE, 2017. Analytical report of the 2016 dengue outbreak in Córdoba city, Argentina. Geospat Health 12:226-36.

Rueda LM, Patel KJ, Axtell RC, Stinner RE, 1990. Temperature dependent development and survival rates of Culex quinquefasciatus and Aedes aegypti (Diptera: Culicidae). J Med Entomol 27:892-8.

Scavuzzo JM, Trucco F, Espinosa M, Tauro CB, Abril M, Scavuzzo CM, Frery AC, 2018. Modeling dengue vector population using remotely sensed data and machine learning. Acta Trop 185:167-75.

Salomón OD, Orellano PW, Lamfri M, Scavuzzo CM, Dri L, Farace MI, Quintana DO, 2006. Phlebotominae spatial distribution asssociated with a focus of tegumentary leishmaniasis in Las Lomitas, Formosa, Argentina, 2002. Memorias Instituto Oswaldo Cruz 101:295-9.

Sarfraz MS, Tripathi NK, Faruque FS, Bajwa UI, Kitamoto A, Souris M, 2014. Mapping urban and peri-urban breeding habitats of Aedes mosquitoes using a fuzzy analytical hierarchical process based on climatic and physical parameters. Geospat Health 8:S685-97.

Tatem AJ, Goetz SJ, Hay SI, 2004. Terra and Aqua: new data for epidemiology and public health. Int J Appl Earth Obs 6:33-46.

Tran A, Deparis X, Dussart P, Morvan J, Rabarison P, Remy F, Polidori L, Gardon J, 2004. Dengue spatial and temporal patterns, French Guiana. Emerg Infect Dis 10:615-21.

Vasconcelos PF, Calisher CH, 2016. Emergence of human arboviral diseases in the Americas, 2000-2016. Vector Borne Zoon Dis 16:295-301.

Wainwright PC, Reilly SM, 1994. Ecological morphology: integrative organismal biology. Chicago, IL: University of Chicago Press.

Wan Z, 1999. MODIS land-surface temperature algorithm theoretical basis document (LST ATBD). Santa Barbara: Institute of Computational Earth System Science.

Wan Z, Zhang Y, Zhang Q, Li ZL, 2004. Quality assessment and validation of the MODIS global land surface temperature. Int J Remote Sens 25:261-74.

Waide RB, Comarazamy DE, González JE, Hall CAS, Lugo AE, Luvall JC, Murphy DJ, Ortiz-Zayas JR, Ramírez-Beltran ND, Scatena FN, Silver WL, 2013. Climate variability at multiple spatial and temporal scales in the Luquillo Mountains, Puerto Rico. Ecol Bull 54:21-41.

World Health Organization (WHO), 2015. Chikungunya. Fact Sheet $\mathrm{N}^{\circ}$ 327. Available from: http://www.who.int/mediacentre/factsheets/fs327/en/

World Health Organization (WHO), 2016. Dengue and severe dengue. Fact Sheet $\mathrm{N}^{\circ} 117$. Available from: http://www.who.int/mediacentre/factsheets/fs117/en/http://ww w.who.int/mediacentre/factsheets/fs117/en/

Wong J, Stoddard ST, Astete H, Morrison AC, Scott TW, 2011. Oviposition site selection by the dengue vector Aedes aegypti and its implications for dengue control. PLoS Negl Trop Dis 5:e1015.

Yang K, Sun LP, Huang YX, Yang GJ, Wu F, Hang DR, Li W, Zhang JF, Liang YS, Zhou XN, 2012. A real-time platform for monitoring schistosomiasis transmission supported by Google Earth and a web-based geographical information system. Geospat Health 6:195-203. 